\title{
Phylogeny, Identification, and Pathogenicity of Lasiodiplodia Associated with Postharvest Stem-End Rot of Coconut in Brazil
}

André Wilson Campos Rosado and Alexandre Reis Machado, Departamento de Fitopatologia, Universidade Federal de Viçosa, Viçosa/MG, 36570-900, Brazil; Francisco das Chagas Oliveira Freire, Embrapa Agroindústria Tropical, Fortaleza/CE, 60511-110, Brazil; and Olinto Liparini Pereira, Departamento de Fitopatologia, Universidade Federal de Viçosa

\begin{abstract}
Rosado, A. W. C., Machado, A. R., Freire, F. C. O., and Pereira, O. L. 2016. Phylogeny, identification, and pathogenicity of Lasiodiplodia associated with postharvest stem-end rot of coconut in Brazil. Plant Dis. 100:561-568.

Coconut palm (Cocos nucifera $\mathrm{L}$.) is one of the most important perennial tropical crops. Stem-end rot is the major postharvest disease of coconut in Brazil. The fungus Lasiodiplodia theobromae is the only species that has been reported to be associated with this disease. However, a comprehensive study elucidating the true identity of this pathogen with molecular tools has never been conducted. In recent years, new species of Lasiodiplodia have been proposed after molecular studies were performed, indicating the existence of a species complex. The aims of this research were to study the etiology of the postharvest stem-end rot of immature coconut

based on a combination of morphological and phylogenetic analyses, to establish the phylogenetic position of such taxa, and to assess the pathogenicity of each taxon. Four species were identified: L. brasiliense, L. egyptiacae, L. pseudotheobromae, and L. theobromae. All of the species were distinguished morphologically and phylogenetically and were proven to be pathogenic to coconut following artificial inoculation. $L$. theobromae was the most common and the most aggressive species. This study represents the first report of three additional species of Lasiodiplodia as causal agents of postharvest stem-end rot of immature coconut in Brazil
\end{abstract}

Cocos nucifera $\mathrm{L}$. is a member of the family Arecaceae and one of the most important perennial tropical crops. Brazil is the fourthlargest producer of coconut, after Indonesia, the Philippines, and India (FAO 2014). The coconut palm is grown widely in Brazil but the northeast states are the largest producers. In 2012, Brazil produced almost 2 billion coconut fruit in an area of approximately 260,000 ha and exported 1,207 t of fruit, generating approximately US $\$ 686,000$. Of these exports, $69 \%$ were produced in the northeast region, occupying nearly 209,000 ha (Informa Economics 2014; IBGE 2014).

Coconut production is limited by several factors, among which diseases play a major role. Stem-end rot is the major postharvest disease of coconut in Brazil, causing significant losses (Viana et al. 2007). The fungus Lasiodiplodia theobromae (Pat.) Griffon \& Maubl. is the only species that has been reported to be associated with this disease (Dingley et al. 1981; Mendes et al. 1998; Piepenbring 2006; Taylor and Hyde 2003). Despite this association, a comprehensive study involving a diversity of isolates of various Brazilian geographic origins to elucidate the true identity of this pathogen with molecular tools has never been conducted.

L. theobromae (Botryosphaeriaceae: Botryosphaeriales: Dothideomycetes: Ascomycota) is cosmopolitan in distribution; however, this species is more commonly found in tropical and subtropical regions (Marques et al. 2013; Punithalingam 1980). This fungus has a wide host range, including gymnosperms and angiosperms, and can occur in nature as a parasite, saprophyte, or endophyte (Alves et al. 2008; Machado et al. 2014b; Slippers and Wingfield 2007). The main characteristics that distinguish Lasiodiplodia from the other related genera are the presence of paraphyses within the pycnidia, and conidia that are initially hyaline and aseptate but become brown and oneseptate with age, forming longitudinal striations due to the deposition of melanin granules on the inner surface of the wall (Hyde et al. 2014; Phillips et al. 2013; Sutton 1980). This fungus is a threat to crops because it can live endophytically in asymptomatic plant material and

Corresponding author: O. Pereira; E-mail: oliparini@ufv.br

Accepted for publication 27 July 2015.

http://dx.doi.org/10.1094/PDIS-03-15-0242-RE

(C) 2016 The American Phytopathological Society avoid detection by quarantine. Moreover, this species can rapidly cause disease when its host is under stress, causing significant losses (Slippers and Wingfield 2007).

Traditionally, the taxonomy of species in Botryosphaeriaceae has been based on the morphology of the anamorphic states, which may underestimate the true diversity of the family (Taylor et al. 2000). Currently, morphological characteristics combined with molecular techniques based on DNA sequences have been used to differentiate taxa of Botryosphaeriaceae and have revealed great diversity (Slippers and Wingfield 2007). Molecular studies have revealed novel species of Lasiodiplodia, demonstrating the existence of a species complex (Abdollahzadeh et al. 2010; Alves et al. 2008; Begoude et al. 2010; Burgess et al. 2006; Damm et al. 2007; Ismail et al. 2012; Linaldeddu et al. 2015; Machado et al. 2014b; Marques et al. 2013; Netto et al. 2014; Pavlic et al. 2004, 2008; Slippers et al. 2014; Urbez-Torres et al. 2012). More cryptic species may be found through molecular studies associated with the morphological characterization of pathogenic Lasiodiplodia spp.

The high losses that are generated by stem-end rot of coconut justify further research into the etiology and the phylogeny of its etiological agents. The accurate identification of pathogens is essential for the proper development of management measures, quarantine programs, and stem-end-rot-resistant coconut varieties. This study combined morphological characteristics with phylogenetic analyses to investigate the diversity of Lasiodiplodia spp. that are associated with the postharvest stem-end rot of immature coconut in Brazil and to assess the pathogenicity of the taxa that were found to be involved in this disease.

\section{Materials and Methods}

Sample collection and isolation. From July to August 2012, coconut fruit with postharvest stem-end rot symptoms were collected from local markets in Viçosa, State of Minas Gerais, Brazil, and sent to the Laboratório de Patologia de Sementes e de Pós-colheita (Departamento de Fitopatologia, Universidade Federal de Viçosa). The samples were first examined for the possible presence of fungal fruiting structures. From these fruit, direct isolations were performed. A mass of conidia was transferred to a petri dish containing $3 \%$ water agar (WA) and spread with a Drigalski spatula, and a single conidium was transferred to a plate containing potato dextrose agar (PDA; Acumedia) under a stereomicroscope $(\times 20$; Motic SMZ-168). The 
plates were incubated at $25^{\circ} \mathrm{C}$ under a 12 -h photoperiod. Additionally, isolates from the states of Bahia (municipality of Juazeiro), Ceará (municipalities of Paraipaba, Pentecoste, Sobral [two isolates], and Trairi], and Paraíba were also obtained from symptomatic fruit. These isolates were grown on petri dishes containing $2 \%$ WA overlaid with double-sterilized maize straw and incubated at $25^{\circ} \mathrm{C}$ under a 12-h near-ultraviolet light regime for 3 to 4 weeks to induce sporulation. Single-spore isolates were obtained as described above. Isolates with dark mycelium, which is a typical characteristic of members of the family Botryosphaeriaceae, were stored in tubes slants on PDA at $10^{\circ} \mathrm{C}$ and in sterile distilled water, as described by Castellani (1967).

DNA extraction, sequencing, and phylogenetic studies. Singlespore isolates were grown on PDA at $25^{\circ} \mathrm{C}$ under a 12 -h photoperiod for 1 week. Approximately $40 \mathrm{mg}$ of mycelia was scraped from the agar surface and placed in a sterile $1.5-\mathrm{ml}$ microcentrifuge tube. Mycelia were ground in liquid nitrogen to a fine powder using a microcentrifuge tube pestle. The crushing was continued after adding $100 \mu \mathrm{l}$ of Nuclei Lysis Solution of the Wizard Genomic DNA Purification Kit (Promega Corp.). After the first grinding, another $500 \mu \mathrm{l}$ of the abovementioned solution was added. The extraction was continued as described by Pinho et al. (2012).

Target sequences of the translation elongation factor $1-\alpha$ (TEF1$\alpha$ ); internal transcribed spacer (ITS) regions 1 and 2, including the 5.8S ribosomal RNA gene; and $\beta$-tubulin ( $\beta \mathrm{t}$ ) were amplified using primers EF1F and EF2R (Jacobs et al. 2004), ITS1 and ITS4 (White et al. 1990), and Bt2a and Bt2b (Glass and Donaldson 1995), respectively. Polymerase chain reaction (PCR) was performed with $12.5 \mu \mathrm{l}$ of Dream Taq PCR Master Mix 2× (MBI Fermentas); $1 \mu 1$ of $10 \mu \mathrm{M}$ each forward and reverse primer, which were synthesized by Invitrogen; $1 \mu$ l of dimethyl sulfoxide (Sigma-Aldrich); $5 \mu$ l of $100 \times$ $(10 \mathrm{mg} / \mathrm{ml}$ ) bovine serum albumin (Sigma-Aldrich,); $2 \mu l$ of genomic DNA ( $25 \mathrm{ng} / \mu \mathrm{l})$; and $2.5 \mu \mathrm{l}$ of nuclease-free water.

The thermal cycle consisted of $95^{\circ} \mathrm{C}$ for 5 min followed by 35 cycles of $94^{\circ} \mathrm{C}$ for $1 \mathrm{~min}$ (denaturation), $55^{\circ} \mathrm{C}$ for $1 \mathrm{~min}$ (for TEF1- $\alpha$ and $\beta \mathrm{t}$ ) or $52^{\circ} \mathrm{C}$ for $1 \mathrm{~min}$ (for ITS) (annealing), $72^{\circ} \mathrm{C}$ for $2 \mathrm{~min}$ (elongation), and $72^{\circ} \mathrm{C}$ for $10 \mathrm{~min}$ (final extension). The PCR products were analyzed by electrophoresis on $2 \%$ agarose gels that were stained with GelRed (Biotium Inc.) in a $1 \times$ Tris-acetate-EDTA buffer and visualized under UV light to check for the amplification size and purity. The amplicons were purified and sequenced by Macrogen Inc. (http://www.macrogen.com/eng/). The nucleotide sequences were edited with the BioEdit software (Hall 2014). All of the sequences were checked manually, and nucleotides with ambiguous positions were clarified using both primer direction sequences. New sequences were deposited in GenBank (http://www.ncbi.nlm.nih.gov). Sequences of selected Lasiodiplodia spp. from GenBank were included in this study (Table 1). Consensus sequences were compared against GenBank's database using their Mega BLAST program. The closest hit sequences were then downloaded in FASTA format and aligned using the multiple sequence alignment program MUSCLE (Edgar 2004), which is built into MEGA v. 6 software (Tamura et al. 2013). The alignments were checked, and manual adjustments were made when necessary. Gaps were treated as missing data. The resulting alignment was deposited into TreeBASE (http://treebase.org/treebase-web/home. html) under accession number S16910.

Bayesian inference (BI) analyses employing a Markov Chain Monte Carlo (MCMC) method were performed with every sequence, first with each gene or locus separately and then with the concatenated sequences (TEF1- $\alpha$, ITS, and $\beta \mathrm{t}$ ). Before launching the BI, the best nucleotide substitution model for each gene was determined with MrMODELTEST 2.3 (Posada and Buckley 2004). Once the likelihood scores were calculated, the models were selected according to the Akaike Information Criterion. The HKY+G model of evolution was used for TEF1- $\alpha$, SYM+I was used for ITS, and GTR+G was used for $\beta$ t. The phylogenetic analysis of the concatenated alignment was performed with the CIPRES web portal (Miller et al. 2010) using MrBayes v. 3.2.3 (Ronquist and Huelsenbeck 2003). In MrBayes, the data were partitioned by locus, and the parameters of the nucleotide substitution models for each partition were set as described above. Four MCMC chains were run simultaneously, starting from random trees, for 10,000,000 generations. The trees were sampled every 1,000 th generation for a total of 10,000 trees. The first 2,500 trees were discarded as the burn-in phase of each analysis. The posterior probabilities (Rannala and Yang 1996) were determined from a majority-rule consensus tree that was generated from the remaining 7,500 trees. The trees were visualized in FigTree (Rambaut 2009) and exported to graphic programs. The tree was rooted with Barriopsis fusca CBS 174.26.

Morphological studies. A representative isolate from each clade identified in the phylogenetic analysis was used for morphological characterization. The isolates were grown on plates containing $2 \%$ WA overlaid with double-sterilized twigs of Pinus spp. or corn straw. The plates were incubated at $25^{\circ} \mathrm{C}$ under a photoperiod of $12 \mathrm{~h}$ with near-ultraviolet light to induce the formation of reproductive structures and sporulation. Sections of the pycnidia were made manually and mounted in lactophenol. Measurements $(n=30)$ of the relevant morphological characteristics (conidia, paraphyses, and conidiogenous cells) were made using a light microscope. Images were obtained with a light microscope that was fitted with a digital camera. Representative isolates of each taxon were deposited in the Coleção Octávio Almeida Drummond culture collection of fungi at the Universidade Federal de Viçosa.

Pathogenicity tests. The isolates that were used for morphological characterization were tested for pathogenicity. For each representative species, three coconut isolates without visible symptoms of disease were inoculated. For inoculation, the isolates were grown on PDA plates for 7 days at $25^{\circ} \mathrm{C}$ under a 12-h photoperiod. The fruit were washed in running water with soap, surface disinfested in $1 \%$ sodium hypochlorite, rinsed in sterile distilled water, and then dried at room temperature. Three fragments of the region near the bracts were removed with a scalpel. A 6-mm-diameter disk containing mycelia from the margins of the growing culture was immediately placed over the wound. As a control, pure PDA plugs $(6 \mathrm{~mm}$ in diameter) were placed on the wounded surfaces of three fruit. All fruit were placed in a transparent plastic box and incubated at $28^{\circ} \mathrm{C}$. Three paper towel layers that were wetted with sterile distilled water were placed at the bottom of each box, and the boxes were wrapped in plastic bags to maintain high humidity levels during incubation. The fruit were kept in the moist chamber for $48 \mathrm{~h}$; then, the plastic bags and paper towels were removed and the fruit were kept at the same temperature.

The aggressiveness of the isolates was assessed by measuring the length $(\mathrm{L})$ and width $(\mathrm{W})$ of the lesion in each fruit 15 days after inoculation. The lesion area was determined using the equation $\mathrm{A}=$ Tlw (Netto et al. 2014; Sakalidis et al. 2011), where A is the area of an oval, 1 is the radius of the length $(\mathrm{L} / 2)$, and $w$ is the radius of the width (W/2). The experiment was conducted in a completely randomized design with three replications per treatment (isolate) and one fruit per replicate. The experiment was conducted twice. The data were analyzed by analysis of variance and means were compared by Tukey's test at 5\% probability using SAS (v. 9.4; Statistical Analysis System). From the symptomatic inoculated fruit, the fungi were reisolated in pure culture as described above.

\section{Results}

Symptomatology and fungal isolation. In symptomatic fruit, black rot begins on the peduncle below the bracts and progresses to the whole fruit, including the endosperm. In older lesions, numerous cirri form on the pycnidia (Fig. 1). In total, 60 isolates of Lasiodiplodia spp. were obtained from the coconut. In addition, some Ceratocystis and Pestalotiopsis isolates were also obtained. Nevertheless, due to the predominance and diversity of Lasiodiplodia spp. that are associated with stem-end rot of coconut, these genera were not included in this work.

PCR amplification and phylogeny. The 60 isolates were compared based on the sequences of the elongation factor (TEF1- $\alpha$ ) region (GenBank accession numbers KP308462 to KP308521) to determine the possible identity of each one (Machado et al. 2014b; Marques et al. 2013; Netto et al. 2014) by means of Bayesian analyses (data not shown). Seventeen isolates representing each of four 
Table 1. GenBank accession numbers of DNA sequences of Lasiodiplodia spp. used in the phylogenetic analyses

\begin{tabular}{|c|c|c|c|c|c|}
\hline \multirow[b]{2}{*}{ Species } & \multirow[b]{2}{*}{ Isolates $^{\mathbf{b}}$} & \multirow[b]{2}{*}{ Host, substrate } & \multicolumn{3}{|c|}{ GenBank accession number ${ }^{a}$} \\
\hline & & & TEF1- $\alpha$ & ITS & $\mathrm{Bt}$ \\
\hline Barriopsis fusca & CBS 174.26 & Unknown & KF766395 & KF766149 & EU673109 \\
\hline Lasiodiplodia brasiliense & CMM4015 & Mangifera indica & JX464049 & JX464063 & $\ldots$ \\
\hline L. brasiliense & CMM2255 & Carica papaya & KC481523 & KC484792 & $\ldots$ \\
\hline L. brasiliense & COAD 1784 & Cocos nucifera & KP308469 & KP244693 & KP308524 \\
\hline L. brasiliense & COAD 1786 & C. nucifera & KP308471 & KP244696 & KP308526 \\
\hline L. brasiliense & COAD 1787 & C. nucifera & KP308470 & KP244695 & KP308527 \\
\hline L. brasiliense & CDA 431 & C. nucifera & KP308472 & KP244694 & KP308525 \\
\hline L. citrícola & IRAN1521C & Citrus sp. & GU945339 & GU945353 & $\ldots$ \\
\hline L. citrícola & IRAN1522C & Citrus sp. & GU945340 & GU945354 & $\ldots$ \\
\hline L. crassispora & CBS110492 & Unknown & EF622066 & EF622086 & EU673134 \\
\hline L. crassispora & CMW22653 & Pterocarpus angolensis & FJ888452 & FJ888465 & $\ldots$ \\
\hline L. egyptiacae & COAD 1791 & C. nucifera & KP308462 & KP244687 & KP308522 \\
\hline L. egyptiacae & BOT29 & M. indica & JN814428 & JN814401 & $\ldots$ \\
\hline L. egyptiacae & CBS 130992 & M. indica & JN814424 & JN814397 & $\ldots$ \\
\hline L. euphorbiicola & CMM3652 & Jatropha curcas & KF226715 & KF234554 & KF254938 \\
\hline L. euphorbiicola & CMM3609 & J. curcas & KF226689 & KF234543 & KF254926 \\
\hline L. exigua & CBS 137785 & Retama raetam & KJ638336 & KJ638317 & $\ldots$ \\
\hline L. exigua & BL 185 & R. raetam & KJ638338 & KJ638319 & $\ldots$ \\
\hline L. gilanensis & IRAN1523C & Unknown & GU945342 & GU945351 & $\ldots$ \\
\hline L. gilanensis & IRAN1501C & Unknown & GU945341 & GU945352 & $\ldots$ \\
\hline L. gonubiensis & CBS115812 & Syzygium cordatum & DQ458877 & DQ458892 & DQ458860 \\
\hline L. hormozganensis & IRAN1500C & Olea sp. & GU945343 & GU945355 & $\ldots$ \\
\hline L. hormozganensis & IRAN1498C & M. indica & GU945344 & GU945356 & $\ldots$ \\
\hline L. iraniensis & IRAN1517C & Citrus sp. & GU945337 & GU945349 & $\ldots$ \\
\hline L. iraniensis & IRAN1519C & M. indica & GU945338 & GU945350 & $\ldots$ \\
\hline L. jatrophicola & CMM3610 & J. curcas & KF226690 & KF234544 & KF254927 \\
\hline L. macrospora & CMM3833 & J. curcas & KF226718 & KF234557 & KF254941 \\
\hline L. mahajangana & CMW27801 & Terminalia catappa & FJ900641 & FJ900595 & FJ900630 \\
\hline L. mahajangana & CMW27820 & T. catappa & FJ900643 & FJ900597 & FJ900632 \\
\hline L. margaritacea & CBS122519 & Adansonia gibbosa & EU144065 & EU144050 & $\ldots$ \\
\hline L. margaritacea & CBS122065 & A. gibbosa & EU144066 & EU144051 & $\ldots$ \\
\hline L. mediterranea & CBS 137783 & Quercus ilex & KJ638331 & KJ638312 & $\ldots$ \\
\hline L. mediterranea & CBS 137784 & Vitis vinifera & KJ638330 & KJ638311 & $\ldots$ \\
\hline L. missouriana & UCD2193M & V. vinifera & HQ288267 & HQ288225 & HQ288304 \\
\hline L. missouriana & UCD2199MO & $V$. vinifera & HQ288268 & HQ288226 & HQ288305 \\
\hline L. parva & CBS456.78 & Cassava-field soil & EF622063 & EF622083 & $\ldots$ \\
\hline L. parva & CBS495.78 & Cassava-field soil & EF622065 & EF622085 & $\ldots$ \\
\hline L. plurivora & STE-U 5803 & V. vinifera & EF445395 & EF445362 & $\ldots$ \\
\hline L. pseudotheobromae & COAD 1785 & C. nucifera & KP308464 & KP244690 & KP308523 \\
\hline L. pseudotheobromae & CBS116459 & Gmelina arborea & EF622057 & EF622077 & EU673111 \\
\hline L. pseudotheobromae & CMM3887 & J. curcas & KF226722 & KF234559 & KF254943 \\
\hline L. pyriformis & CBS 121770 & Acacia mellifera & EU101352 & EU101307 & $\ldots$ \\
\hline L. pyriformis & CBS 121771 & A. mellifera & EU101353 & EU101308 & $\begin{array}{l}\cdots \\
\cdots\end{array}$ \\
\hline L. rubropurpurea & WAC 12536 & Eucalyptus grandis & DQ103572 & DQ103554 & $\ldots$ \\
\hline L. subglobosa & CMM3872 & $J$. curcas & KF226721 & KF234558 & KF254942 \\
\hline L. subglobosa & CMM4046 & J. curcas & KF226723 & KF234560 & KF254944 \\
\hline L. theobromae & CBS 164.96 & Unknown & AY640258 & AY640255 & EU673110 \\
\hline L. theobromae & CBS 124.13 & Unknown & DQ458875 & DQ458890 & DQ458858 \\
\hline L. theobromae & COAD 1788 & C. nucifera & KP308476 & KP244698 & KP308528 \\
\hline L. theobromae & COAD 1789 & C. nucifera & KP308474 & KP244700 & KP308529 \\
\hline L. theobromae & COAD 1790 COAD 1789 & C. nucifera & KP308468 & KP244703 & KP308530 \\
\hline L. theobromae & CDA 425 & C. nucifera & KP308475 & KP244697 & KP308531 \\
\hline L. theobromae & CDA 444 & C. nucifera & KP308477 & KP244699 & KP308532 \\
\hline L. theobromae & CDA 450 & C. nucifera & KP308478 & KP244688 & KP308533 \\
\hline L. theobromae & CDA 455 & C. nucifera & KP308463 & KP244689 & KP308534 \\
\hline L. theobromae & CDA 465 & C. nucifera & KP308465 & KP244701 & KP308535 \\
\hline L. theobromae & CDA 467 & C. nucifera & KP308473 & KP244702 & KP308536 \\
\hline L. theobromae & CDA 469 & C. nucifera & KP308466 & KP244691 & KP308537 \\
\hline L. theobromae & CDA 472 & C. nucifera & KP308467 & KP244692 & KP308538 \\
\hline L. theobromae & CMW28571 & T. ivorensis & GQ469897 & GQ469924 & $\ldots$ \\
\hline L. theobromae & CBS111530 & Unknown & EF622054 & EF622074 & $\ldots$ \\
\hline L. venezuelensis & WAC12539 & A. mangium & DQ103568 & DQ103547 & $\cdots$ \\
\hline L. venezuelensis & CMW13513 & A. mangium & DQ103570 & DQ103549 & $\cdots$ \\
\hline L. viticola & UCD2604MO & $V$. vinifera & HQ288270 & HQ288228 & HQ288307 \\
\hline L. viticola & UCD2553AR & V. vinifera & HQ288269 & HQ288227 & HQ288306 \\
\hline
\end{tabular}

a TEF1- $\alpha=$ translation elongation factor 1- $\alpha$; ITS = internal transcribed spacer regions 1 and 2, including the 5.8S ribosomal RNA gene; and $\beta \mathrm{t}=\beta$-tubulin.

${ }^{\mathrm{b}}$ Isolates obtained in this study are highlighted in bold. COAD = Coleção Octávio Almeida Drummond at the Universidade Federal de Viçosa. 
putative species were selected, and ITS and $\beta$ t sequences were obtained. PCR was successfully performed with $2 \mu$ l of genomic DNA for every isolate, except for isolate CDA 472 (TEF1- $\alpha$ ) which was amplified using $4 \mu \mathrm{l}$. Amplicons of approximately 740, 500, and $430 \mathrm{bp}$ were generated for TEF1- $\alpha$, ITS, and $\beta \mathrm{t}$, respectively. The sequences were deposited in GenBank (Table 1).

The combined phylogenetic analyses (TEF1- $\alpha$, ITS, and $\beta \mathrm{t}$ ) included 61 taxa, and the alignment of the sequences resulted in a total of 1,232 characters, of which 137 were parsimony-informative, 233 were variable, and 976 were conserved. The phylogenetic analysis revealed four species of Lasiodiplodia: L. brasiliense (M. S. B. Netto, M. W. Marques \& A. J. L. Phillips), L. egyptiaca (A. M. Ismail, L. Lombard \& Crous), L. pseudotheobromae (A. J. L. Phillips, A. Alves \& Crous), and L. theobromae. These species were grouped into four clades (Fig. 2). The majority of isolates $(n=11)$ formed a large clade with $L$. theobromae with a Bayesian posterior probability (BPP) value of 0.96. A second well-supported clade $(\mathrm{BPP}=0.90)$ with four isolates was formed together with $L$. brasiliense, a species that was recently described from papaya. One isolate clustered together with L. egyptiacae and another with L. pseudotheobromae with high BPP values (0.94 and 1, respectively).

$L$. theobromae was the most frequently isolated species (54 isolates) obtained from Juazeiro $(n=17)$, Paraíba $(n=1)$, Pentecoste $(n=1)$, Sobral $(n=2)$, Trairi $(n=1)$, and Viçosa $(n=32)$; followed by $L$. brasiliense ( 4 isolates) from Juazeiro $(n=1)$, Paraipaba $(n=1)$, and Viçosa $(n=2)$. Only one isolate each of L. egyptiacae and L. pseudotheobromae was found, both in Viçosa.

Taxonomy. All of the isolates that sporulated in culture medium showed typical Lasiodiplodia morphology. Paraphyses were present within the pycnidial conidiomata. The conidia were initially hyaline and aseptate and became brown and one-septate with age, forming longitudinal striations (Fig. 3). Based on phylogenetic analysis and morphological characteristics, four species were identified: L. brasiliense, L. egyptiacae, L. pseudotheobromae, and L. theobromae. The dimensions of each Lasiodiplodia sp. are available in Table 2.

Pathogenicity tests. All of the isolates were pathogenic to coconut, resulting in visible lesions 4 days after inoculation. The symptoms included dark-brown necrotic lesions with grayish mycelial growth around the inoculation sites, progressing to cover the whole fruit. During the development of the disease, numerous conidial cirri on pycnidia were observed, and the fungus invaded internal tissues, including the endosperm. There were differences $(P<0.05)$ in the aggressiveness among the Lasiodiplodia spp. L. theobromae was the most aggressive of all the tested species, causing large lesions $\left(28.3 \mathrm{~cm}^{2}\right)$. The other species had lesions of 14.1 to $17.2 \mathrm{~cm}^{2}$ and
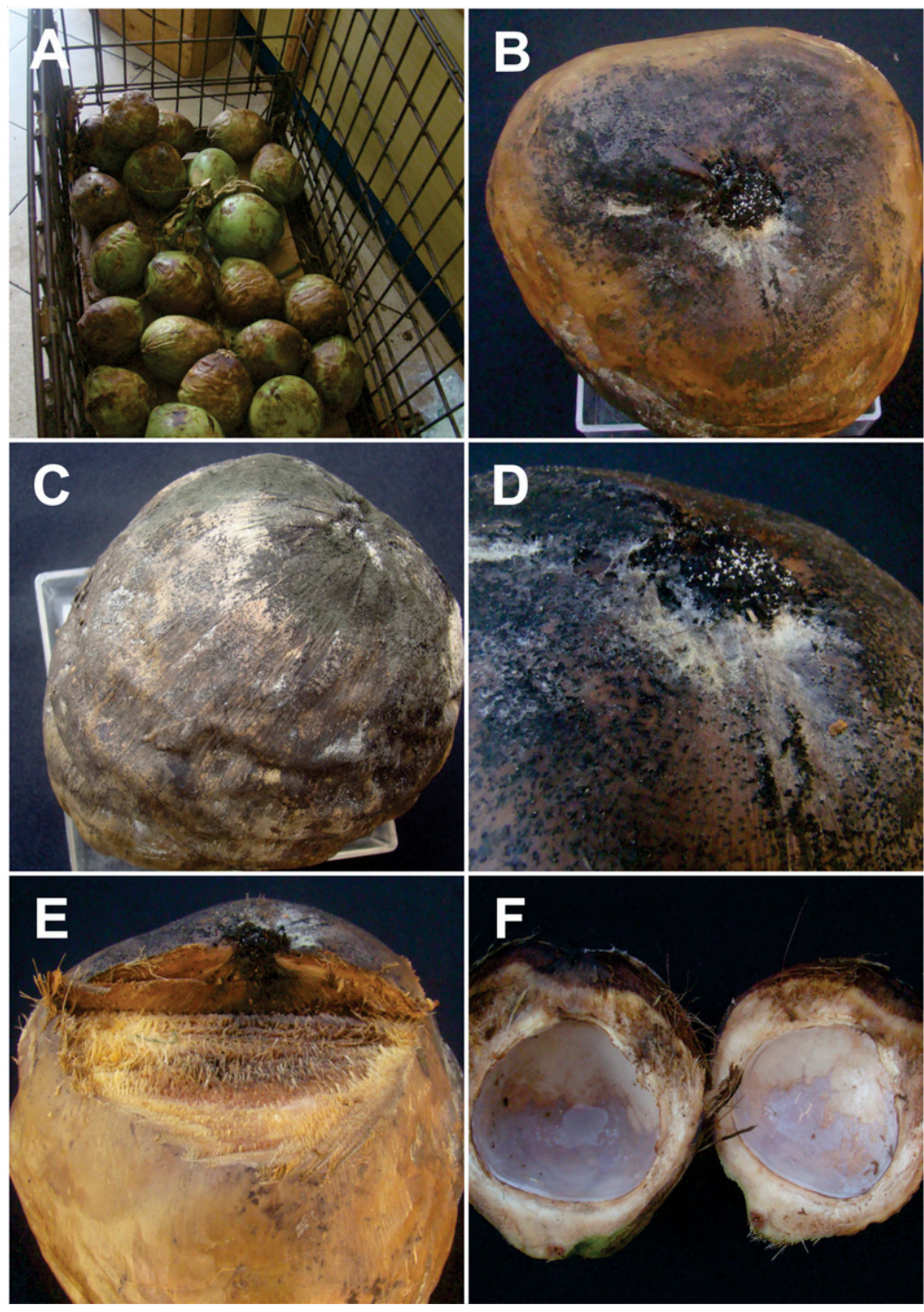

Fig. 1. Symptoms of stem-end rot in coconut fruit. A, Fruit presenting stem-end rot symptoms for sale in a local market; $\mathbf{B}$ and $\mathbf{C}$, symptomatic fruit, with the disease beginning on the peduncle and progressing to the whole fruit; $\mathbf{D}$, fruit with numerous cirri formed on the pycnidia; and $\mathbf{E}$ and $\mathbf{F}$, longitudinal sections showing the fungus progressing into the endosperm. 
differed significantly from the control (Fig. 4). The respective species were reisolated from the diseased tissues, fulfilling Koch's postulates.

\section{Discussion}

For many years, the etiology of postharvest stem-end rot of coconut was neglected by researchers and, despite the importance of this disease, only L. theobromae had been reported as a pathogen to coconut. This work is the first study involving phylogenetic and morphological analyses of Lasiodiplodia isolates of various Brazilian geographic origins associated with postharvest stem-end rot of immature coconut. Four species of Lasiodiplodia were identified in association with the symptomatic fruit.

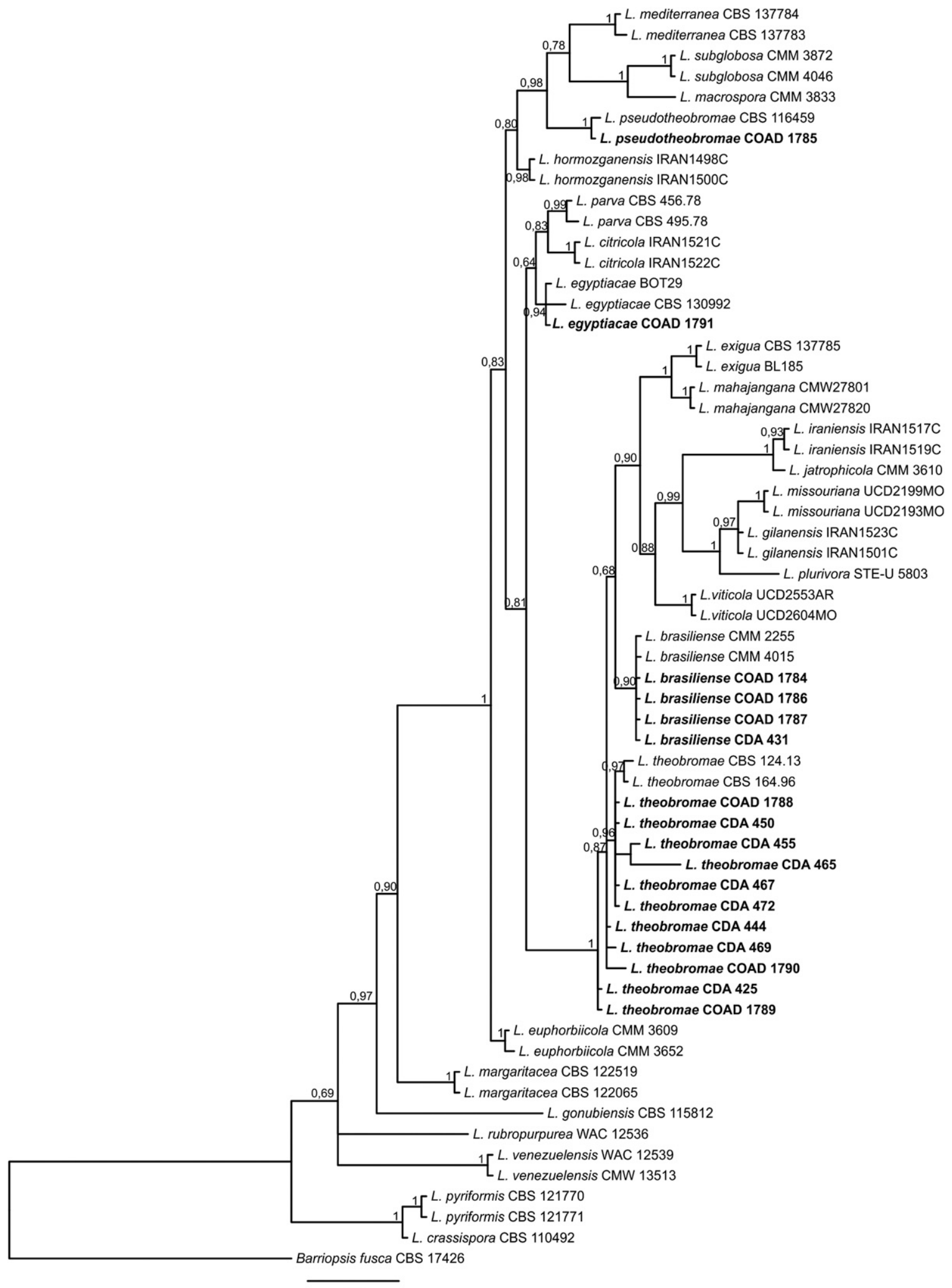

Fig. 2. Multilocus phylogenetic tree as inferred from a Bayesian analysis based on the combined sequences of translation elongation factor 1- $\alpha$; internal transcribed spacer regions 1 and 2, including the 5.8S ribosomal RNA gene; and $\beta$-tubulin. The Bayesian posterior probabilities are indicated next to the nodes. The tree was rooted with Barriopsis fusca CBS 174.26. Representative species that were selected for this study are highlighted in bold. 
Corroborating previous studies on the application of molecular phylogenetic techniques in Lasiodiplodia spp., it was possible to separate the four species using only the TEF1- $\alpha$ gene (Machado et al. 2014b; Marques et al. 2013; Netto et al. 2014). In addition to the
TEF1- $\alpha$ sequences that were generated and analyzed here, other genes (ITS and $\beta \mathrm{t}$ ) were included to increase the phylogenetic support to confirm the distinction of the species. The four known species that were identified in this study clustered in a well-supported clade
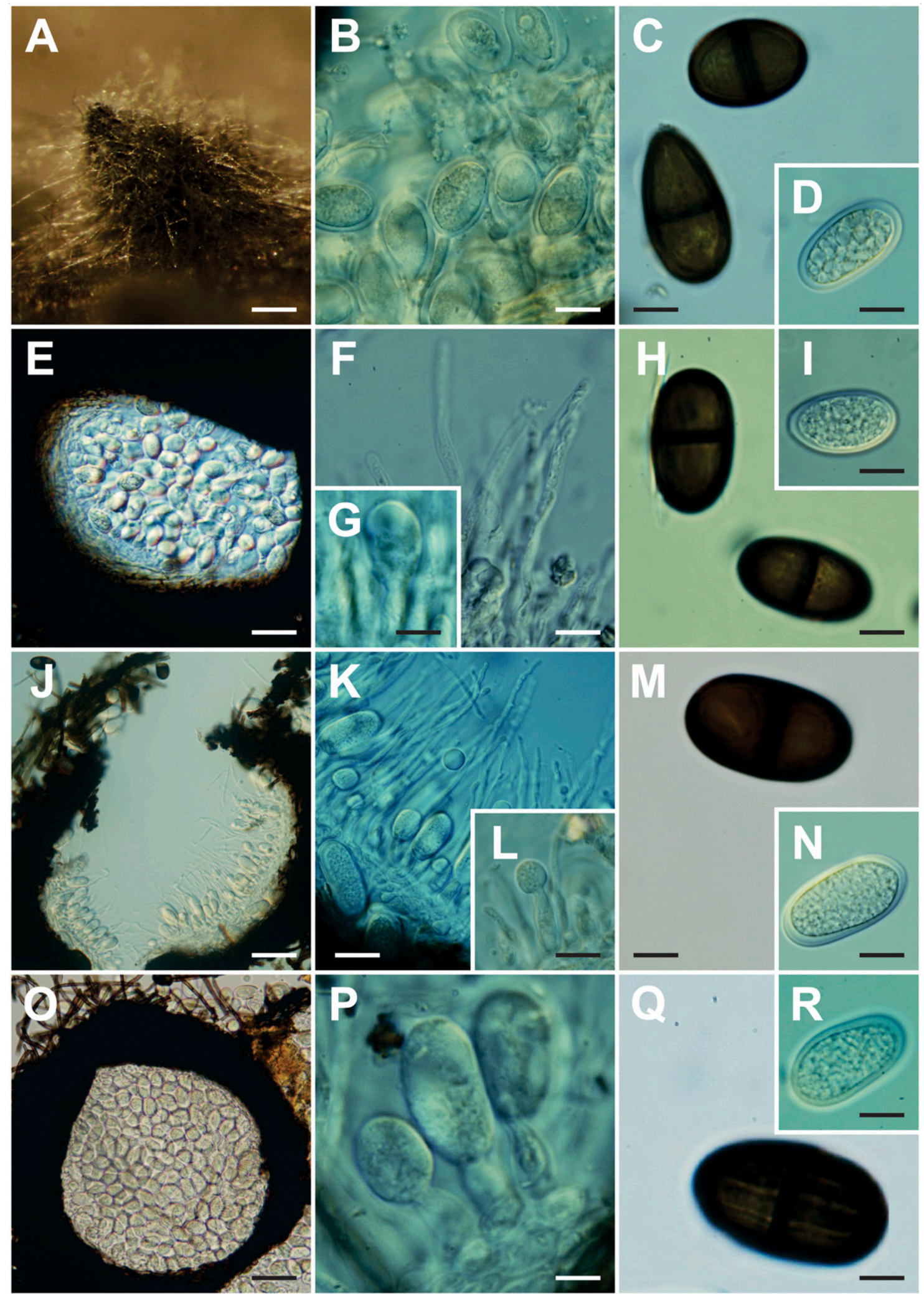

Fig. 3. A to D, Lasiodiplodia brasiliense. A, Conidioma on Pinus twigs in culture; B, conidia developing on conidiogenous cells; C, mature conidia with longitudinal striations; and D, hyaline, immature conidia. E to I, L. egyptiacae. E, Section of a conidioma; F, aseptate paraphyses; G, conidia developing on conidiogenous cells; $\mathbf{H}$, mature conidia; and I, immature conidia. J to N, L. pseudotheobromae. J, Section of a conidioma; K, septate and branched paraphyses; L, conidia developing on conidiogenous cells; $\mathbf{M}$, mature conidia; and $\mathbf{N}$, immature conidia. $\mathbf{O}$ to $\mathbf{R}, \mathbf{L}$. theobromae. $\mathbf{0}$, Section of a conidioma; P, conidia developing on conidiogenous cells; $\mathbf{Q}$, mature conidia; $\mathbf{R}$, immature conidia. Scale bars: $A=500 \mu \mathrm{m} ; B$ to $D, F$ to I, $K$ to $N$, and $P$ to $R=10 \mu \mathrm{m} ; E, J$, and $O=50 \mu \mathrm{m}$. 
with other isolates examined in previously published studies (Alves et al. 2008; Ismail et al. 2012; Netto et al. 2014; Phillips et al. 2013). Species of Lasiodiplodia have been differentiated based on phylogenetic analysis and morphological characteristics. The most frequently described morphological characteristics include conidial and paraphyses morphology and, to a lesser extent, cultural characteristics (growth and pigment production) (Linaldeddu et al. 2015; Machado et al. 2014b; Marques et al. 2013; Netto et al. 2014; Slippers et al. 2014).

Characteristics of pycnidial paraphyses must be carefully interpreted. The fungus can show aseptate paraphyses when young but these paraphyses may develop septa as they mature (Abdollahzadeh et al. 2010). L. theobromae has been reported with septate paraphyses (Alves et al. 2008) but, in our study, no septate paraphyses were found, suggesting this to be a variable characteristic. L. pseudotheobromae was previously described as having aseptate paraphyses (Alves et al. 2008) but, in our study, paraphyses were septate, in agreement with the observation of Machado et al. (2014b). The other morphological characteristics that were analyzed for these two species were similar to those found in previous studies. The fungus L. pseudotheobromae has a cosmopolitan distribution, occurring in a broad range of hosts, including Acacia mangium, A. mellifera, cassava, Citrus aurantium, coffee, eucalyptus, Gmelina arborea, mango, Myrcianthes pungens, papaya, physic nut, rose, and Terminalia catappa (Abdollahzadeh et al. 2010; Alves et al. 2008; Begoude et al. 2010; Machado et al. 2014a,b; Marques et al. 2013; Netto et al. 2014; Pérez et al. 2010; Phillips et al. 2013; Slippers et al. 2014; Zhao et al. 2010).

The conidia of $L$. brasiliense in this study were similar to those previously described by Netto et al. (2014), and were longer and wider than the conidia of the closely related species $L$. viticola. It is not possible to distinguish between these two species solely based on the TEF1- $\alpha$ gene (data not shown) (Netto et al. 2014). Therefore, other genes (ITS and $\beta \mathrm{t}$ ) are essential to clarify the phylogenetic position of this species. Prior to this article, this species had only been reported in papaya and mango (Netto et al. 2014).

The conidia, paraphyses, and conidiogenous cells of L. egyptiacae were bigger than those described by Ismail et al. (2012) but similar to the dimensions reported by Machado et al. (2014b). This fungus was described in mango but also occurs in physic nut (Ismail et al. 2012; Machado et al. 2014b; Marques et al. 2013).

L. theobromae was the most frequently encountered species in this study, similar to the studies of Marques et al. (2013) and Netto et al. (2014) and confirming the wide distribution of $L$. theobromae in Brazil. The second most frequently encountered species was L. brasiliense. Only one isolate each of L. egyptiacae and L. pseudotheobromae was found. Similar results were found by Marques et al. (2013), in which L. egyptiacae was the second least frequently isolated species, and by Netto et al. (2014), in which L. pseudotheobromae was the least frequently isolated species.

All of the isolates were pathogenic to coconut. In addition to devaluation of the crop due to esthetic damage, Lasiodiplodia spp. can also progress into the endosperm, rendering the coconut water unfit for consumption and resulting in significant monetary losses. $L$. theobromae was the most aggressive of all the tested species. Thus, L. theobromae is both the most common and most aggressive species that is associated with the postharvest stem-end rot of immature coconut. Information on this species and its aggressiveness is scarce, and further research is required.

This work represents the first report of L. brasiliense, L. egyptiacae, and $L$. pseudotheobromae in addition to L. theobromae as causal agents of the postharvest stem-end rot of immature coconut. These

Table 2. Main morphological characteristics of Lasiodiplodia spp. reported on coconut in Brazil

\begin{tabular}{|c|c|c|c|c|c|}
\hline \multirow{2}{*}{$\frac{\text { Species }}{\text { Lasiodiplodia brasiliense }}$} & \multirow{2}{*}{$\begin{array}{c}\text { Conidia }(\boldsymbol{\mu m}) \\
22.7-29.2 \times 11.7-17\end{array}$} & \multicolumn{2}{|c|}{ Paraphyses $(\mu \mathrm{m})$} & \multirow{2}{*}{$\begin{array}{c}\text { Conidiogenous cells }(\mu \mathrm{m}) \\
\ldots\end{array}$} & \multirow{2}{*}{$\begin{array}{r}\text { Reference } \\
\text { Netto et al. } 2014\end{array}$} \\
\hline & & $\ldots$ & Aseptate & & \\
\hline & $20-26 \times 12-18$ & $61 \times 2-3$ & Aseptate & $9-17 \times 2-4$ & This study \\
\hline \multirow[t]{3}{*}{ L. egyptiacae } & $20-24 \times 11-12$ & $57 \times 2-3$ & Aseptate & $5-11 \times 3-5$ & Ismail et al. 2012 \\
\hline & $22-29 \times 14-17$ & $75 \times 2-4$ & Aseptate & $5-19 \times 3-5$ & Machado et al. 2014b \\
\hline & $21.5-29 \times 11-17.5$ & $75.5 \times 2-3$ & Aseptate & $7-20 \times 2-5$ & This study \\
\hline \multirow[t]{3}{*}{ L. pseudotheobromae } & $23.5-32 \times 14-18$ & $58 \times 3-4$ & Aseptate & & Alves et al. 2008 \\
\hline & $26-31 \times 13-16$ & $65 \times 2-3$ & Septate & $5-15 \times 2-5$ & Machado et al. 2014b \\
\hline & $25-32 \times 14-18$ & $65 \times 2-3$ & Septate & $8-17 \times 3-4$ & This study \\
\hline \multirow[t]{4}{*}{ L. theobromae } & $21-31 \times 13-15.5$ & $55 \times 3-4$ & Septate & $\ldots$ & Alves et al. 2008 \\
\hline & $20-30 \times 10-15$ & $55 \times-$ & $\ldots$ & $5-15 \times 3$ & Sutton 1980 \\
\hline & $23-31 \times 13-15$ & $45 \times 2$ & Aseptate & $5-11 \times 2-4$ & Machado et al. 2014b \\
\hline & $18.5-30.5 \times 12-18$ & $65 \times 2-4$ & Aseptate & $7-14 \times 2-4$ & This study \\
\hline
\end{tabular}

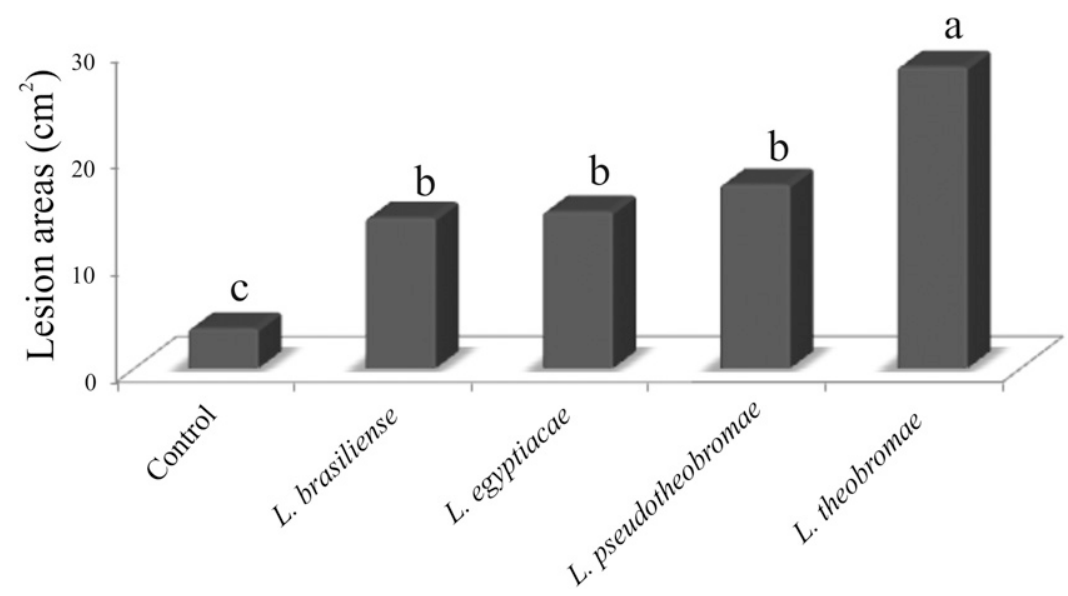

Fig. 4. Mean lesion areas caused by Lasiodiplodia spp. that are associated with postharvest stem-end rot of immature coconut in Brazil. Columns with the same letter do not differ significantly according to Tukey's test $(P<0.05)$. 
results indicate the great diversity of Lasiodiplodia spp. that are associated with coconut stem-end rot. The results of this study may be helpful for further studies on management measures, quarantine programs, or the development of stem-end-rot-resistant coconut varieties.

\section{Acknowledgments}

This work forms part of a research project that was submitted as an M.Sc. dissertation to the Departamento de Fitopatologia/Universidade Federal de Viçosa by A. W. C. Rosado. We thank the Conselho Nacional de Desenvolvimento Científico e Tecnológico, Fundação de Amparo a Pesquisa do Estado de Minas Gerais for financial support of the work; and the Coordenação de Aperfeiçoamento de Pessoal de Nível Superior for author fellowships.

\section{Literature Cited}

Abdollahzadeh, J., Javadi, A., Mohammadi Goltapeh, E., Zare, R., and Phillips, A. J. L. 2010. Phylogeny and morphology of four new species of Lasiodiplodia from Iran. Persoonia 25:1-10.

Alves, A., Crous, P. W., Correia, A., and Phillips, A. J. L. 2008. Morphological and molecular data reveal cryptic speciation in Lasiodiplodia theobromae. Fungal Divers. 28:1-13.

Begoude, B. A. D., Slippers, B., Wingfield, M. J., and Roux, J. 2010. Botryosphaeriaceae associated with Terminalia catappa in Cameroon, South Africa and Madagascar. Mycol. Prog. 9:101-123.

Burgess, T. I., Barber, P. A., Mohali, S., Pegg, G., de Beer, W., and Wingfield, M. J. 2006. Three new Lasiodiplodia spp. from the tropics, recognized based on DNA sequence comparisons and morphology. Mycologia 98:423-435.

Castellani, A. 1967. Maintenance and cultivation of common pathogenic fungi of man in sterile distilled water: Further researches. J. Trop. Med. Hyg. 70: 181-184.

Damm, U., Crous, P. W., and Fourie, P. H. 2007. Botryosphaeriaceae as potential pathogens of Prunus species in South Africa, with descriptions of Diplodia africana and Lasiodiplodia plurivora sp. nov. Mycologia 99:664-680.

Dingley, J. M., Fullerton, R. A., and McKenzie, E. H. C. 1981. Records of fungi, bacteria, algae and angiosperms pathogenic on plants in Cook Islands, Fiji, Kiribati, Niue, Tonga, Tuvalu and Western Samoa. In: Survey of Agricultural Pests and Diseases, Technical Report, vol. 2. FAO, Rome.

Edgar, R. C. 2004. MUSCLE: Multiple sequence alignment with high accuracy and high throughput. Nucleic Acids Res. 32:1792-1797.

FAO. 2014. FAOSTAT. Online publication. Food and Agriculture Organization of the United Nations. http://faostat3.fao.org/faostat-gateway/go/to/download/Q/QC/E/

Glass, N. L., and Donaldson, G. C. 1995. Development of primer sets designed for use with the PCR to amplify conserved genes from filamentous ascomycetes. Appl. Environ. Microbiol. 61:1323-1330.

Hall, T. 2014. BioEdit v. 7.0.9: Biological sequence alignment editor for Win95/98/NT/2K/XP/7. Online publication. http://www.mbio.ncsu.edu/bioedit/ bioedit.html

Hyde, K. D., Nilsson, R. H., Alias, S. A., Ariyawansa, H. A., Blair, J. E., Cai, L., de Cock, A. W. A. M., Dissanayake, A. J., Glockling, S. L., Goonasekara, I. D., Gorczak, M., Hahn, M., Jayawardena, R. S., van Kan, J. A. L., Laurence, M. H., Lévesque, C. A., Li, X., Liu, J.-K., Maharachchikumbura, S. S. N., Manamgoda, D. S., Martin, F. N., McKenzie, E. H. C., McTaggart, A. R., Mortimer, P. E., Nair, P. V. R., Pawłowska, J., Rintoul, T. L., Shivas, R. G., Spies, C. F. J., Summerell, B. A., Taylor, P. W. J., Terhem, R. B., Udayanga, D., Vaghefi, N., Walther, G., Wilk, M., Wrzosek, M., Xu, J.-C., Yan, J., and Zhou, N. 2014. One stop shop: Backbones trees for important phytopathogenic genera: I (2014). Fungal Divers. 67:21-125.

IBGE. 2014. Instituto Brasileiro de Geografia e Estatística. Online publication. http://www.sidra.ibge.gov.br/bda/tabela/listabl.asp?c=1613\&z=t\&o=11

Informa Economics FNP. 2014. Coco-da-baía. Pages 270-276 in: Agrianual: Anuário da agricultura brasileira. C. P. Pastrello, B. Silva, M. Silvestre, and J. J. Canto, eds. São Paulo, Brazil.

Ismail, A. M., Cirvilleri, G., Polizzi, G., Crous, P. W., Groenewald, J. Z., and Lombard, L. 2012. Lasiodiplodia species associated with dieback disease of mango (Mangifera indica) in Egypt. Australas. Plant Pathol. 41:649-660.

Jacobs, K., Bergdahl, D. R., Wingfield, M. J., Halik, S., Seifert, K. A., Bright, D. E., and Wingfield, B. D. 2004. Leptographium wingfieldii introduced into North America and found associated with exotic Tomicus piniperda and native bark beetles. Mycol. Res. 108:411-418.

Linaldeddu, B. T., Deidda, A., Scanu, B., Franceschini, A., Serra, S., BerrafTebbal, A., Zouaoui Boutiti, M., Ben Jamâa, M. L., and Phillips, A. J. L. 2015. Diversity of Botryosphaeriaceae species associated with grapevine and other woody hosts in Italy, Algeria and Tunisia, with descriptions of Lasiodiplodia exigua and Lasiodiplodia mediterranea sp. nov. Fungal Divers. 71:201-214.

Machado, A. R., Pinho, D. B., de Oliveira, S. A. S., and Pereira, O. L. 2014a. New occurrences of Botryosphaeriaceae causing black root rot of cassava in Brazil. Trop. Plant Pathol. 39:464-470.

Machado, A. R., Pinho, D. B., and Pereira, O. L. 2014b. Phylogeny, identification and pathogenicity of the Botryosphaeriaceae associated with collar and root rot of the biofuel plant Jatropha curcas in Brazil, with a description of new species of Lasiodiplodia. Fungal Divers. 67:231-247.

Marques, M. W., Lima, N. B., Morais, M. A., Jr., Barbosa, M. A. G., Souza, B. O., Michereff, S. J., Phillips, A. J. L., and Câmara, M. P. S. 2013. Species of Lasiodiplodia associated with mango in Brazil. Fungal Divers. 61:181-193.

Mendes, M. A. S., Silva, V. L., Dianese, J. C., Ferreira, M. A. S. V., Santos, C. E. N., Gomes Neto, E., Urben, A. F., and Castro, C. 1998. Fungos em plantas no Brasil. Embrapa-SP/Embrapa-Cenargen, Brasília, Brazil.

Miller, M. A., Pfeiffer, W., and Schwartz, T. 2010. Creating the CIPRES Science Gateway for inference of large phylogenetic trees. In: Proc. Gateway Comput. Environ. Workshop (GCE), New Orleans, LA. Online publication. doi: 10.1109/GCE.2010.5676129

Netto, M. S. B., Assunção, I. P., Lima, G. S. A., Marques, M. W., Lima, W. G. Monteiro, J. H. A., Balbino, V. Q., Michereff, S. J., Phillips, A. J. L., and Câmara, M. P. S. 2014. Species of Lasiodiplodia associated with papaya stem-end rot in Brazil. Fungal Divers. 67:127-141.

Pavlic, D., Slippers, B., Coutinho, T. A., Gryzenhout, M., and Wingfield, M. J. 2004. Lasiodiplodia gonubiensis sp. nov., a new Botryosphaeria anamorph from native Syzygium cordatum in South Africa. Stud. Mycol. 50:313-322.

Pavlic, D., Wingfield, M. J., Barber, P., Slippers, B., Hardy, G. E. S. J., and Burgess, T. I. 2008. Seven new species of the Botryosphaeriaceae from baobab and other native trees in Western Australia. Mycologia 100:851-866.

Pérez, C. A., Wingfield, M. J., Slippers, B., Altier, N. A., and Blanchette, R. A. 2010. Endophytic and canker-associated Botryosphaeriaceae occurring on non-native Eucalyptus and native Myrtaceae trees in Uruguay. Fungal Divers. 41:53-69.

Phillips, A. J. L., Alves, A., Abdollahzadeh, J., Slippers, B., Wingfield, M. J., Groenewald, J. Z., and Crous, P. W. 2013. The Botryosphaeriaceae: Genera and species known from culture. Stud. Mycol. 76:51-167.

Piepenbring, M. 2006. Checklist of fungi in Panama. Preliminary version. Puente Biol. 1:1-190.

Pinho, D. B., Firmino, A. L., Ferreira-Junior, W. G., and Pereira, O. L. 2013. An efficient protocol for DNA extraction from Meliolales and the description of Meliola centellae sp. nov. Mycotaxon 122:333-345.

Posada, D., and Buckley, T. R. 2004. Model selection and model averaging in phylogenetics: Advantages of Akaike Information Criterion and Bayesian approaches over likelihood ratio tests. Syst. Biol. 53:793-808.

Punithalingam, E. 1980. Plant Diseases Attributed to Botryodiplodia theobromae. Pat. In: Bibliotheca Mycologica Series, no 71, J. Cramer, Vaduz, Liechtenstein

Rambaut, A. 2009. FigTree 1.2.2. Online publication. http://tree.bio.ed.ac uk/software/figtree

Rannala, B., and Yang, Z. 1996. Probability distribution of molecular evolutionary trees: A new method of phylogenetic inference. J. Mol. Evol. 43:304-311.

Ronquist, F., and Huelsenbeck, J. P. 2003. MrBayes 3: Bayesian phylogenetic inference under mixed models. Bioinformatics 19:1572-1574.

Sakalidis, M. L., Ray, J. D., Lanoiselet, V., Hardy, G. E. S. J., and Burgess, T. I. 2011. Pathogenic Botryosphaeriaceae associated with Mangifera indica in the Kimberley region of Western Australia. Eur. J. Plant Pathol. 130:379-391.

Slippers, B., Roux, J., Wingfield, M. J., Van der Walt, F. J. J., Jami, F., Mehl, J. W. M., and Marais, G. J. 2014. Confronting the constraints of morphological taxonomy in the Botryosphaeriales. Persoonia 33:155-168.

Slippers, B., and Wingfield, M. J. 2007. Botryosphaeriaceae as endophytes and latent pathogens of woody plants: Diversity, ecology and impact. Fungal Biol. Rev. 21:90-106.

Sutton, B. C. 1980. The Coelomycetes: Fungi Imperfecti with Acervuli, Pycnidia and Stromata. Commonwealth Mycological Institute, Kew, UK

Tamura, K., Stecher, G., Peterson, D., Filipski, A., and Kumar, S. 2013. MEGA6: Molecular evolutionary genetics analysis version 6.0. Mol. Biol. Evol. 30: $2725-2729$

Taylor, J. E., and Hyde, K. D. 2003. Microfungi of Tropical and Temperate Palms Fungal Diversity Research Series 12 . Fungal Diversity Press, Hong Kong.

Taylor, J. W., Jacobson, D. J., Kroken, S., Kasuga, T., Geiser, D. M., Hibbett, D. S., and Fisher, M. C. 2000. Phylogenetic species recognition and species concepts in fungi. Fungal Genet. Biol. 31:21-32.

Urbez-Torres, J. R., Peduto, F., Striegler, R. K., Urrea-Romero, K. E., Rupe, J. C., Cartwright, R. D., and Gubler, W. D. 2012. Characterization of fungal pathogens associated with grapevine trunk diseases in Arkansas and Missouri. Fungal Divers. 52:169-189.

Viana, F. M. P., Uchôa, C. N., Freire, F. C. O., Vieira, I. G. P., Mendes, F. N. P., and Saraiva, H. A. O. 2007. Tratamento do coco verde para exportação com ênfase no controle da podridão-basal-pós-colheita. In: Boletim de pesquisa e desenvolvimento 29, Embrapa Agroindústria Tropical, Fortaleza, Ceará, Brazil.

White, T. J., Bruns, T., Lee, S., and Taylor, J. 1990. Amplification and direct sequencing of fungal ribosomal RNA genes for phylogenetics. Pages 315-322 in: PCR Protocols: A Guide to Methods and Applications. M. A. Innis, D. H. Gelfand, J. J. Sninsky, and T. J. White, eds. Academic Press, San Diego, CA.

Zhao, J. P., Lu, Q., Liang, J., Decock, C., and Zhang, X. Y. 2010. Lasiodiplodia pseudotheobromae, a new record of pathogenic fungus from some subtropical and tropical trees in southern China. Cryptogam., Mycol. 31: 431-439. 